Research Paper / Araştırma Makalesi

\title{
Üniversite Öğrencilerinin Covid-19 Dönemi Duygu ve Durumlarına İlişkin Tutumları: KKTC Örneği
}

\author{
İrem KARATAŞ ${ }^{1}$, Merve AKKILIÇ ${ }^{2}$ ve Özlem ALTUN ${ }^{3}$
}

Öz

Çin'in Wuhan kentinde ilk covid-19 vakasının bildirilmesinden sonra virüs önce Çin sonra tüm dünya ülkelerinde hızla yayılmış ve evrensel bir pandemi sürecini başlamasına neden oluştur. Bu durum insanların birçok sosyal ve ekonomik yaşam alanında olumsuz etkilere sebep olmuştur. Bu çalışmanın amacı KKTC'de Üniversitelerinde okuyan öğrencilerin covid-19 dönemi duygu ve durumlarına ilişkin geçerli, güvenilir ve yeni bir tutum ölçeği geliştirmektir. Hazırlanmış olan ankette, 5 dereceli Likert tipi, 30 sorudan oluşan anket formu KKTC'de üniversitelerinde okuyan 203 kişiye uygulanmış, bunlardan 200 adeti değerlendirilmek için uygun görülmüştür. Elde edilen verilerin istatistiksel hesaplamaları SPSS 24.0 ve AMOS 24.0 istatistik programı kullanılmıştır. Güvenirlilik ve geçerliliğine ilişkin veriler elde edilerek, ölçek kullanıma hazır hale gelmiştir. Gerçekleştirilen analizler sonucunda, elde dilen değerler verilerin uyumunun iyi düzeyde olduğu belirlenmiştir. Buna ek olarak, çoklu regrasyon analizi sonucuna göre genel olarak cinsiyet ve yaş değişkenleri ile covid-19 dönemi duygu ve durumları ölçeği arasında anlamlı bir olduğu belirlenirken katılımcıların okudukları bölüm ile covid-19 dönemi duygu ve durumları ölçeği arasında anlamlı bir ilişki olmadığ1 belirlenmiştir.

Anahtar Kelimeler: Korona virüs, Salgın, Covid-19, Pandemi, Üniversite öğrencileri, KKTC

\section{University Students 'Attitudes About Covid-19 Period Emotion and Status: Case Of} TRNC

\section{Abstract}

The first covid-19 case was reported in Wuhan, China, spread rapidly in all countries of the world. They started a universal pandemic process. This situation has caused negative effects on the social and economic life of people. The aim of this study is to develop a valid, reliable, and new attitude scale regarding the feelings and situations of the students studying at their universities in the TRNC during the covid-19 period. In the questionnaire form consisting of 5 Likert type, 30 questions were applied to 203 students studying at universities in the TRNC, 200 of which were deemed suitable for evaluation. SPSS 24.0 and AMOS 24.0 software were used for statistical calculations. The scale has become ready for use by obtaining data on its reliability and validity. As a result of the analyses carried out, it was determined that the data obtained were at a good level. In addition, according to the results of the multiple regression analysis, it was determined that there was a significant relationship between the gender and age variables and the covid-19 period emotions and states scale, while there was no significant relationship between the department where they study and the covid-19 period emotions and states scale.

Key Words: Coronavirus, Outbreak, Covid-19, Pandemic, University students, TRNC

\section{Atıf İçin / Please Cite As:}

Karataş, İ., Akkılıç, M. ve Altun, Ö. (2021). Üniversite öğrencilerinin Covid-19 dönemi duygu ve durumlarına ilişkin tutumları: KKTC örneği. Manas Sosyal Araștırmalar Dergisi, 10(4), 2137-2147.

Geliş Tarihi / Received Date: 04.01.2021

Kabul Tarihi / Accepted Date: 11.05.2021

1 Yüksek Lisans Öğrencisi - İstanbul Ticaret Üniversitesi, Turizm İşletmeciliği, iremkaratas05@gmail.com

iD ORCID: 0000-0002-5962-0306

2 Yüksek Lisans Öğrencisi - Uluslararası Kıbrıs Üniversitesi, mrvakkilic@gmail.com

D ORCID: 0000-0001-5072-4523

${ }^{3}$ Yrd. Doç. Dr. - Doğu Akdeniz Üniversitesi, Turizm Fakültesi, ozlem.altun@emu.edu.tr

(iD ORCID: 0000-0002-0830-002X 


\section{Giriş}

Salgın hastalıklar, diğer küresel çaplı olumsuzluklardan daha fazla önem arz etmektedir (Acar, 2020, s. 9). Bulaşıcılık özelliğinden dolayı destinasyon imajını ve güvenilirlik özelliğini etkilemektedir. 31 Aralık 2019 tarihinde Çin'in Wuhan şehrinde, deniz ürünleri pazarında ortaya çıkan ve covid-19 ismi verilen virüsü ulusal ve uluslararası alanda yıkımlara yol açmıştır. Covid-19 virüsünün, küresel alanda bu denli yayılmasını sağlayan en büyük unsur uluslararası alanda gerçekleştirilen turizm faaliyetleri neden olmuştur (Ariyaratne, 2020, s. 8).

Ancak covid-19 virüs salgınından etkilenen tek sektör turizm ve turizm faaliyetleri olmamıştır (Soylu, 2020, s. 184). İnsanların toplu olarak bir arada bulundukları kapalı alanlarda eğitim gördükleri gibi yurtiçinde ve yurt dişında eğitim gören öğrenciler maddi ve manevi olarak oldukça olumsuz etkilenmiştir. Covid19 virüsünün yayılmasını engellemek ve insanların kendilerini izole edebilmeleri adına kısmen ve tamamen sokağa çıkma yasakları getirilmiştir. Bu durum beraberinde pandemi sürecinin başlamasına neden olmakla birlikte pandemi süresince dünya genelinde olgu gibi birçok sektörde ve özellikle eğitim alanında da internet aracilığıyla evde çalışma ve eğitim sistemine geçilmiştir (Bozkurt, 2020, s. 115).

Turizm değişen dünya ve ülke şartlarına en hızlı şekilde adapte olan bir dinamiğe sahiptir. Turizm, küresel alanda ilgi odağı olan, seçilen destinasyonlara ciddi parasal gelir sağlayan, festival gibi durumlarda bölge halkının kalkınmasına yardımcı olan bir faaliyet ile ülkelere büyük katkılar ile etki etmektedir. Ancak ülkelerin siyasi yapılarına bağlı kalarak gelişen terör saldıralı gibi küresel çapta turizmi etkileyecek salgın hastalıklar beklenmedik çapta turizmi kötü etkilemektedir (Sheresheva, 2020, s. 74). KKTC'deki en büyük turizm gelir hareketliliği üniversite öğrencilerinden ve kumar turizminden sağlanmaktadır. Ancak ortaya çıkan bu salgın hastalık KKTC destinasyonuna olan güveni kırmaktadır. KKTC'de alınan önlemler doğrultusunda üniversitelerin eğitime geçici bir süre ara verilip daha sonrasında uzaktan eğitim sistemi olan online eğitime geçilmiştir.

Bu çalısmada, KKTC üniversitelerinde okuyan öğrencilerin covid-19 dönemi duygu ve durumlarındaki değişimleri belirleyebilmek hedeflenmiştir. Araştırmanın önemi, KKTC'de okuyan üniversite öğrencilerinin çoğunluğu ailelerinden uzakta okuyan öğrencilerdir. Bu sebeple hem öğrencilerdeki covid-19 dönemi duygu ve durumlarını ölçerken, bir yandan ailelerinden uzakta kalan öğrencilerde de gerçekleșen covid-19 dönemi duygu ve durum değişiklikleri ölçmeye yönelik olduğu için oldukça önem taşımaktadır.

\section{Literatür İncelemesi}

SARS-CoV-2 enfeksiyonu salgını, Dünya Sağlık Örgütü (WHO) tarafindan korona virüs hastalı̆̆1 2019 (covid-19) olarak adlandırılmıştır (Üstün ve Özçiftçi, 2020, s. 145). Covid-19 virüsü hızla bir şekilde tüm dünya ülkelerine yayılmış ve 11 Mart 2020 tarihinde 4000'den fazla insanın ölümüne yol açması durumunda, Dünya Sağlık Örgütü tarafindan bu tarihte resmî olarak pandemi ilan edilmiştir (Çöl, 2020, s. 7). $\mathrm{Bu}$ virüsün kaynağı net olarak bilinmemekle birlikte, Huanan deniz ürünleri toptan satış pazarında satılan vahşi hayvanlardan bulaştı̆̆ı düşünülmektedir (Aktuğ, 2020, s. 519). Hastalık oldukça hızlı bir bulaşıcılık özelliğine sahip olmakla birlikte en belirgin semptomları ateş, kuru öksürük, yorgunluk, kas ağrısı ve nefes darllğıdır.

Covid-19 virüsünün kontrolünde en önemlisi olan izolasyonun hem fizyolojik hem de psikolojik olarak insanlar üzerinde birçok yan etkisi vardır (Karatosun, 2010, s. 9). Bireylerin izolasyon sürecini sağlıklı geçirebilmeleri için bulundukları yaşam şartlarına uyum sağlamaları oldukça önem taşımaktadır. Karantina süresinde, ruhsal ve fiziksel sağlı durumlarını koruyabilmek için bireylerin aktif kalmaları ve fiziksel olarak egzersizlerini normale göre daha dikkatli ve kontrollü yapmaları gerekmektedir (Karatosun, 2010, s. 11). İnsanların karantina sonrasındaki yaşam düzenlerinin değişmemesi ve sağlıklarının bozulmaması adına evde normal düzende aktif yaşamlarını devam ettirmeleri oldukça önemlidir (Aktuğ, 2020, s. 515).

Sağlık bakanlığı; ateş, öksürük, nefes darlığı semptomlarından en az birisi olan ve semptomların başlamasından 14 gün önce kendi veya yakının yurt dışı seyahat gerçekleştirme gibi durumlanı olan kişiler, covid-19 hastası ile yakın temasa geçmiş ve aynı zamanda başka nedenle açıklanamayan hastanelerde yatarak tedavi olan ağır bir şekilde solunum enfeksiyonu geçiren kişiler ve beraberinde ani başlangıçlı ateş ve hiç durmayan bir öksürük veya nefes darlığı, burun akıntısı problemi yaşama-yan kişilerin de covid-19 hastaları şeklinde değerlendirilmektedir. Olası semptomları olan kişiler ilk olarak fizik muayene edilmektedir (Crawford vd., 2020, s. 19). Fiziki muayene edilip tanı konulamayan kişilerde ise tam kan sayımı, Creaktif protein, akciğer grafiği veya bilgisayarlı tomografi önerilmektedir. Test sonucu pozitif çıkan kişiler 
için tedavi sürecinin başlaması durumunda kendilerini izolasyon kurallarına uymaları koşulu ile evlerinde tedavi edilirler (Dikmen ve Özkan, 2020, s. 33).

$\mathrm{Bu}$ tür salgın hastalık durumlarında hem doğrudan hem de dolaylı olarak etkilenmiş olan insanların tutum ve davranışları bunları içerebilir: geçim olanaklarını kaybetme korkusu, izolasyon esnasında ve sonrasında çalışamama korkusu, işten çıkarılma korkusu, hastalıkla ilişkili olarak karantinaya alınması sırasında ve sonrasında sosyal dışlanmaya neden olacağ korkusu, sıkılma gibi yalnızlık hissetme ve depresyon, hastalğa yakalanma durumundan sonra ölme korkusu, bakım sırasında yaşadıklarına bağlı korkular nedeni ile sağlık tesislerine gitmekten kaçınma, sevdiklerini koruma konusundaki kendilerini güçsüz hissetme, salgın nedeniyle sevdiklerini kaybetme korkusu gibi bir çok durumla karşı karşıya gelmeleri yaşanan zorlu süreçten sonra insanlarda kalıcı veya geçici davranış bozuklukları bırakmaktadır (Şenışık, 2015, s. 15).

Pandemi süresince dünya çapında alınan önlemlerden en önemlisi seyahatlere getirilen kıstlamalar (Gössling, Scott ve Hall, 2020, s. 12). İnsanların salgin sirasinda seyahatlerine devam etmesinden dolay1 havalimanları salgının yayılma konusunda en tehlikeli alanlar arasında yer almaktaydı. Bundan dolayı uçuşlar esnasında uyulması gereken kurallar ve alınması gereken önlemler adına dokümanlar yayınlanmıştır. Ancak daha sonrasında başta covid-19 virüsünün ortaya çıtı̆̆̆ bölge olmak üzere ülkelere giriş ve çıkışlar duraklatılmıştır (Akca, 2020, s. 51). Bu duraklatılma beraberinde ülkelerin uluslararası çapta turist girişini engellemiştir (Macit ve Macit, 2020, s. 106). Ulusal ve uluslararasında gerçekleşmesi beklenen tüm spor dallarında olumsuzluklar meydana gelmiştir. Salgından dolayı dünya çapında gerçekleşmesi gereken spor turnuvalar1 duruma göre 2021'e ertelenmesine ya da iptaline karar verilmiştir. Bu durum spor turizmi üzerinde olumsuz gelişmelere neden olmuştur. Hemen hemen dünyanın tüm spor liglerinde, UEFA'nın uluslararası etkinliklerine ve çok branşlı uluslararası spor organizasyonlarında olumsuzluk meydana gelmiştir (Türkmen ve Özsar1, 2020, s. 61).

Dünya çapında ünlü Formula 1 yarışları, Fransa'da gerçekleştirilen bisiklet turunun ve dünyaca önemli at yarışı iptali ülkelerin spor turizmini olumsuz yönde etkilemiştir. Tokyo 2020 (Türkmen ve Özsarı, 2020) Olimpiyatları ise Japonya'nın 2020 Olimpiyatlarına yönelik esnettiği yasaları da etkilemiştir. Bu yasalara örnek vermek gerekirse, Japonya'da kumar turizmi ülke yönetimince yasaklanmış, ancak Tokyo 2020 Olimpiyatları döneminde ülke yönetimince kumar turizminin yasallaştırılması gibi durumlar meydana gelmiştir. Türkiye'nin covid-19 salgınından dolayı, turizm kapsamında kurum ve kuruluşların talepleri olmuştur. TÜRSAB tarafindan kurum ve kuruluşların talepleri, Kültür ve Turizm Bakanlığı'na iletilmiştir. Bu taleplerin içeriği daha çok işletme sahiplerinin SGK, KDV ve vergiler gibi yll içerisinde belirli periyotlarla ödemesi zorunlu olan ödemelerin ertelenmesi gibi isteklerdir. Ayrıca banka kredilerinin, elektrik, su ve doğal gaz gibi zorunlu giderlerinde ödenmesinde kolayllk talep edilmiştir. Bunlara ek olarak ülkelerin ekonomisine oldukça katkı sağlayan turizm sektöründe ise istihdam destekleri, ülkemize turizm talebini arttırıcı desteklerin çoğaltılması ve uçak gibi ulaşım firmalarına olan desteğin arttırılması gibi talepleri içermektedir (TÜRSAB, 2020). Talepler doğrultusunda alınan kararlar 17 Nisan 2020 tarihinde, 31102 sayılı Resmî Gazetede gelişmelere yönelik alınan kararlar yayınlanmıştır.

Covid-19 salgını nedeniyle KKTC'deki otellerin, restoranların yanı sıra tüm toplu yemek yeme alanlarında kısıtlamalar meydana gelmiştir. Covid-19 virüsü solunum yolu, ağız yolu ve damlacıklar şeklinde insanlara bulaşmaktadır. Bunu engelleyebilmek için yemek hizmeti veren mekânlar, oteller vb. alanlar geçici süreliğine kapatılmışır (Şen, 2020, s. 96). Kapatılmayan yerler ise temizlik ve hijyen kurallarına ekstra dikkat etmeye başlamışlardır. Maske ve eldiven kullanımı arttırılmıştır. Covid-19 virüs salgını, başta Çin olmak üzere yayıldığı her ülkenin ekonomi, çevresel, sosyolojik ve kültürel olmak üzere her alanda insan yaşamını olumsuz etkilemiştir. Uluslararası alanda her ülke, uzmanların ve yetkililerin önerdiği önlemler çerçevesinde hareket etmek oluşabilecek bütün riskleri azaltma açısında büyük önem taşımaktadır (Niewiadomski, 2020, s. 652). Toplum sağlığını tehlikeye atmamak adına ülkelerin büyük önlemler almaları gerekmektedir. Turizm alanında alınan önlemler toplum sağlı̆ı adına oldukça önem taşımaktadır. Ülkeler önlemlerini almalarıyla birlikte, turizm destinasyonu güveni artacaktır. Bu sanc1lı süreci geçirdiğimizde turistler destinasyon imajına ve güvenine göre karar vereceklerdir. Covid-19 salgını nedeniyle alınan önlemler sosyal bilimler alında çalışan araştırmacılar ve uzmanlar tarafından önerilen önlemler alınmıştır. Alınan önlemlerin hem kriz yönetimi sırasında hem de krizden sonrası için olumlu gelişmelere neden olacağı değerlendirilmiştir (İbiş, 2020, s. 89).

Covid-19 virüs salgınından insanları koruyabilmek adına, pandemi süresinde eğitim internet aracilığıyla devam etmeye başlanmıştır. Ancak bireylerin duygu ve durumlarında değişiklikler gerçekleşmiş̧ir. Pandemi süresinde insanlar sosyal yaşantılarından ve normal yaşantılarından uzaklaştıkları için her açıdan 
olumsuz sonuçlar oluşmasına sebep olmuştur (Toquero, 2020, s. em0063). Oluşan bu olumsuzluklar insanların ruhsal durumlarında değişikliklere neden olmuştur. Bunları engelleyebilmek adına internet platformlarında insanlar için organizasyonlar gerçekleştirilmiştir (Schleicher, 2020, s. 33). İnternet ortamında tiyatro ve benzeri gibi sahne sanatlarına dayalı birçok konsere internet erişimi kolaylığ getirilmiştir (Demuyakor, 2020, s. e202018).

KKTC'de covid-19 virüs salgını nedeniyle 2020 yllının Mart ayında yüz yüze eğitime ara verilerek online eğitime geçilmiştir. Bununla birlikte üniversite öğrencileri ailelerinin yanlarına geri dönerek adadan ayrılmışlardır. Buna ek olarak adada yaşayan yerli halkın, öğrencilerden sağladığı eğitim turizmindeki gelir kaynağında azalmalar meydana gelmiştir. Ayrıca üniversite öğrencilerinde yaşanan bu değişim beraberinde duygu ve durumlarında birtakım olumsuzluklara neden olmuştur. Eğitime ara vermemek adına KKTC'de tüm ilköğretim, ortaöğretim, lise ve üniversitelerde sistem internet üzerine kurularak devam edilmiştir. Buna ek olarak tüm sınavlarda erteleme kararı alınmıştır (Durak ve Çankaya, 2020, s. 790). Gerçekleştirilen tüm eğitim, kültür ve sanat organizasyonları ile insanlardaki değişimin önüne geçerek, pandemi süresini daha rahat ve sağlıklı geçirebilmek hedeflenmiştir (Liu vd., 2020, s. e17; Pakpour ve Griffiths, 2020, s. 4).

\section{Yöntem}

Alanyazında da belirtildiği gibi dünya genelinde yaşamı olağanüstü derecede etkisi altına alan covid-19 virüsü her alanda insanları olumsuz açıdan etkilemiştir. Bununla birlikte eğitimin aktif olarak devam ettiği döneme denk gelmesiyle birlikte KKTC'de üniversite okuyan öğrencileri de etkilemiştir. Gerçekleştirilmiş olan bu çalışmada, KKTC üniversitelerinde okuyan öğrencilerin covid-19 dönemi duygu ve durumlarını incelemek amacıyla bir ölçme aracının geliştirilmesi hedeflenmiştir. Ayrıca buna bağlı kalarak cinsiyet, yaş ve okudukları okul ile covid-19 dönemi duygu ve durum faktörleriyle arasındaki ilişkiyi belirlemek hedeflenmiştir.

\section{Evren-Örneklem}

Gerçekleştirilmiş olan bu çalışma evren olarak, KKTC'de, üniversite düzeyinde eğitim gören genç bireyler tercih edilmiştir. Dolayısıyla, çalışmanın örneklemi KKTC'de bulunan 7 farklı üniversitede eğitim gören 203 öğrenciden oluşturmaktadır.

\section{Veri Toplama Araçları}

Anket. Bu araştırma KKTC'de bulunan öğrencilerin covid-19 dönemi duygu ve durumlarını ölçen beşli Likert tipi ölçek modeline uygun şekilde tasarlanmış bir ölçek geliştirmek amacıyla hazırlanmıs, geçerlilik ve güvenilirlik analizleri gerçekleştirilmiştir.

Eğitim araştırmalarında sıklıkla ölçülmeye çalşılan değişkenlerden biri de tutumdur. Tezbaşaran’a (1997) göre, tutum, "belirli nesne, durum, kurum, kavram ya da diğer insanlara karşı öğrenilmiş, olumlu ya da olumsuz tepkide bulunma eğilimi” olarak tanımlanmıştır. Bu çalışmanın ölçeği aşağıdaki aşamalarla hazırlanmıştır. Maddeler hazırlanırken covid-19 ve salgınlar ile ilgili çeşitli literatür kaynakları taranmıştır. $\mathrm{Bu}$ konularla ilgili yapılmış çalışmalar ve benzeri çalışmalar incelenmiştir. Kullanılan ölçekler ve elde edilen veriler incelenmiştir. Yapılan incelemeler sonucu taslağın hazırlanması için benzer çalışmalardan faydalanılarak ulaşılan bilgilerden yararlanılmıştır. Alanında uzman kişilerden konu ile ilgili görüş alınarak veriler toplanmaya çalışılmıştır. 40 madde oluşturulmuştur.

Bunun sonucunda oluşturulan madde sayısı uzman görüşüne başvurularak eleme yoluna gidilmiştir, elemenin ardından 15'i olumsuz 15’i olumlu olmak üzere toplam 30 soru hazırlanmıştır. Soruların son halleri Türkçe alanında uzman bir kişiye sunularak gerekli düzenlemeler yapılmıştır. 203 anketten 200 tanesine sağlıklı cevaplar verilmiştir, 3 anket iptal edilmiştir. Ardından düzenlemesi yapılan sorular bir form haline getirilmiş ve daha sonra sağlık alanında uzman 3 akademisyene sunulmuştur. Soruların KKTC'deki üniversitelerinde okuyan öğrencilerin covid-19 dönemi duygu ve durumları ile ilgili tutumlarını ölçüyor olması uzmanlar tarafından incelendikten sonra konuyla ilgili görüş alınmıştır. Örnek form da seçeneklerin yan tarafina uzman görüşü almak için boş bırakılan "değerlendirme" sütununa gerekli fikirler verildikten sonra uzmanlara verilen formlar toplanarak arasindaki tutarllıklar incelenmisstir.

Pilot çalışma sonucunda hakemlerin geri dönüşüne göre ve pilot çalışmaya katılan katılımcıların geri dönüşlerine göre yeniden düzenlenen ölçek KKTC’de bulunan 7 farklı üniversitede eğitim gören 203 öğrenci tarafindan doldurulmuştur. Oluşturulan anket formu, öğrencilere araştırma hakkında bilgi içeren açıklayıcı bir e-posta ile gönderilmiş ve çalışmaya katılabilmeleri için bir link adresi verilmiştir. Çalışmaya katılmak isteyen öğrenciler internet ortamında doldurarak göndermişlerdir. Katıllımcilardan her ifadeyi 
okuduktan sonra "kesinlikle katılmıorum" ile "kesinlikle katıllyorum" arasında değişen 5'li Likert tipi yanıt seçeneklerinden kendileri için en uygun seçeneği seçip işaretlemeleri istenmiştir.

\section{Verilerin Analizi}

Araştırmanın analiz aşamasında, SPPS 24.0 ve AMOS 24.0 programları kullanılmıştır. Ayrıca sırsıyla demografik, açıklayıcı faktör analizi (AFA), doğrulayıcı faktör analizi (DFA), güvenilirlik analizi ve çoklu regresyon analizi uygulanmıştır.

\section{Bulgular}

Bu çalışmadaki demografik bulgular Tablo 1'de görüldüğü üzere, katılımcı sayısı 200 kişidir. 113 kadın katılımc1, 87 erkek katılımcı mevcuttur. Katılımcıların \%56,5'ini kadın katılımcılar oluştururken, \%43,5'ini erkek katılımcılar oluşturmaktadır. Katılımcıların yaş aralığı $18-25$ ve üzeri arasında ardışık verilmiştir. Veriler sonucunda en fazla katılımı \%32 oranla ve 64 kişi olarak 24-25 yaş arasındaki öğrenciler göstermiş, en az kathlım da \%1 oranla ve 2 kişi olarak 18-19 yaş grubu göstermiştir. Yedi farklı üniversiteden katılım sağlanmıştır, katılımı 104 kişi ile \%52 gibi büyük bir çoğunlukla Uluslararası Kıbrıs Üniversitesi’nde okuyan öğrenciler oluşturmaktadır, 40 kişi ve \%20 oranında bir katılım ile Doğu Akdeniz Üniversitesi 2. sıradadır, 24 kişi ve $\% 12$ oranında bir katılım ile Lefke Avrupa Üniversitesi 3. sıradadır, 16 kişi ve \%8 oranında bir katılım ile Yakın Doğu Üniversitesi 4. sıradadır, 9 kişi ve \%4.5 oranında bir katılım ile Orta Doğu Teknik Üniversitesi 5. sıradadır, 5 kişilik ve \%2.5 oranında bir katılım ile Girne Üniversitesi 6. sıradadır. En az katılımı ise 2 kişi ile \%1 oranla Girne Amerikan Üniversitesi oluşturmaktadır.

Tablo 1. Demografik Bulgular ( $n=200$ )

\begin{tabular}{|c|c|c|c|}
\hline & Tanimlar & $n$ & $\%$ \\
\hline \multirow{2}{*}{ Cinsiyet } & Kadın & 113 & 56.5 \\
\hline & Erkek & 87 & 43.5 \\
\hline \multirow{6}{*}{ Yaş } & $18-19$ & 2 & 1.0 \\
\hline & $19-20$ & 8 & 4.0 \\
\hline & $20-21$ & 50 & 25.0 \\
\hline & $22-23$ & 58 & 29.0 \\
\hline & $24-25$ & 64 & 32.0 \\
\hline & 25 ve üzeri & 18 & 9.0 \\
\hline \multirow{7}{*}{ Okul Adı } & Yakın Doğu Üniversitesi & 16 & 8.0 \\
\hline & Girne Amerikan Üniversitesi & 2 & 1.0 \\
\hline & Uluslararası K1brıs Üniversitesi & 104 & 52.0 \\
\hline & Orta Doğu Teknik Üniversitesi (KKTC) & 9 & 4.5 \\
\hline & Girne Üniversitesi & 5 & 2.5 \\
\hline & Lefke Avrupa Üniversitesi & 24 & 12.0 \\
\hline & Doğu Akdeniz Üniversitesi & 40 & 20.0 \\
\hline
\end{tabular}

Tablo 2'de verilen bilgilere göre, verilerin güvenilirlik ve geçerlilik analizi sonuçları verilmiştir. Güvenilirlik analizinden önce, ölçek ile elde edilen verilerin geçerlilik analizi yapılmıştır (Altunışık, Coşkun, Bayraktaroğlu ve Yıldırım, 2007, s. 70). Bu analiz kapsamında açıklayıcı ve doğrulayıcı faktör analizi uygulanmıştır (Şencan, Veri Analizi, t.y.). Analizler sırasına göre ilk açıklayıcı faktör analizi yapılmış olup daha sonrasında doğrulayıcı faktör analizi uygulanmıştır. Açıklayıcı faktör analizi ile ölçekte kullanılan maddelerde faktör yükü 0.50 'nin altındaki maddeler daha sonraki analiz işleminde doğru sonuçlar alınabilmesi amacıyla çıkarılmıştır (Çakmur, 2012, s. 342). Tablo 2 incelendiğinde açılayıc1 faktör analizi ve doğrulayıc1 faktör analizleri sonucunda hiçbir maddenin faktör yükü 0.50 'nin altında bir değere sahip değildir. Buna ek olarak verilerin asıl yapısının faktör analizine uygunluğunu saptayabilmek adına KMO (Kaiser-MeyerOlkin) ve Bartlett's testi uygulanarak Tablo 2'de de sonuçlarına yer verilmiştir. Elde edilen KMO (0.77) katsayısı değeri iyi derece kabul edilebilir çıarken, Bartlett's testi sonucu $(1920.724=p<0.05)$ anlamlı çıkmışır (Doğan ve Başokçu, 2010, s. 69). AFA için açıklanan toplam varyansları sırasıyla, birinci faktör için $\% 29.049$, ikinci faktör için $\% 16.853$, üçüncü faktör için $\% 10.746$, dördüncü faktör için $\% 6.524$ ve son olarak beşinci faktör için de \%5.632 olarak sonuçlar elde edilmiştir. Çalısmada güvenilirlik analizi için Cronbach Alpha değerine yer verilmiştir (Ercan ve Kan, 2004, s. 215). Bu doğrultuda elde edilen de değer 0.82 ile kabul edilebilir düzeyde olduğu belirlenmiştir (Kılıç, 2016, s. 48).

Faktör analizi üzerine kurulu çok değişkenli analizlerin ve gizli yapıları içeren, hipotezlerin ilişkilerini belirleyen uyumu endekslerini belirlemek amaciyla yapılan analiz türüdür (Schermelleh-Engel, Moosbrug- 
ger ve Müller, 2003, s. 33). Gerçekleştirilen bu araştırmada uyum endekslerini belirlemek amacıyla CMIN, CMIN/DF, NFI, CFI, IFI, RMR ve RMSEA değerlerine yer verilmiştir (Erkorkmaz, Etikan, Demir, Özdamar ve Sanisoğlu, 2013, s. 217). Elde edilen değerlerin sonuçları CMIN (488.568), CMIN/DF (3.441), NFI (0.75), CFI (0.81), IFI (0.81), RMR (0.08) ve RMSEA (0.11) iyi derecede kabul edilebilir olduğu saptanmıştır (Şencan, 2005, s. 15). Gerçekleştirilmiş analizler sonucunda elde dilen değerler verilerin uyumunun iyi düzeyde olduğu saptanmıştır.

Tablo 2. Faktör Analizi ve Güvenilirlik Analizi

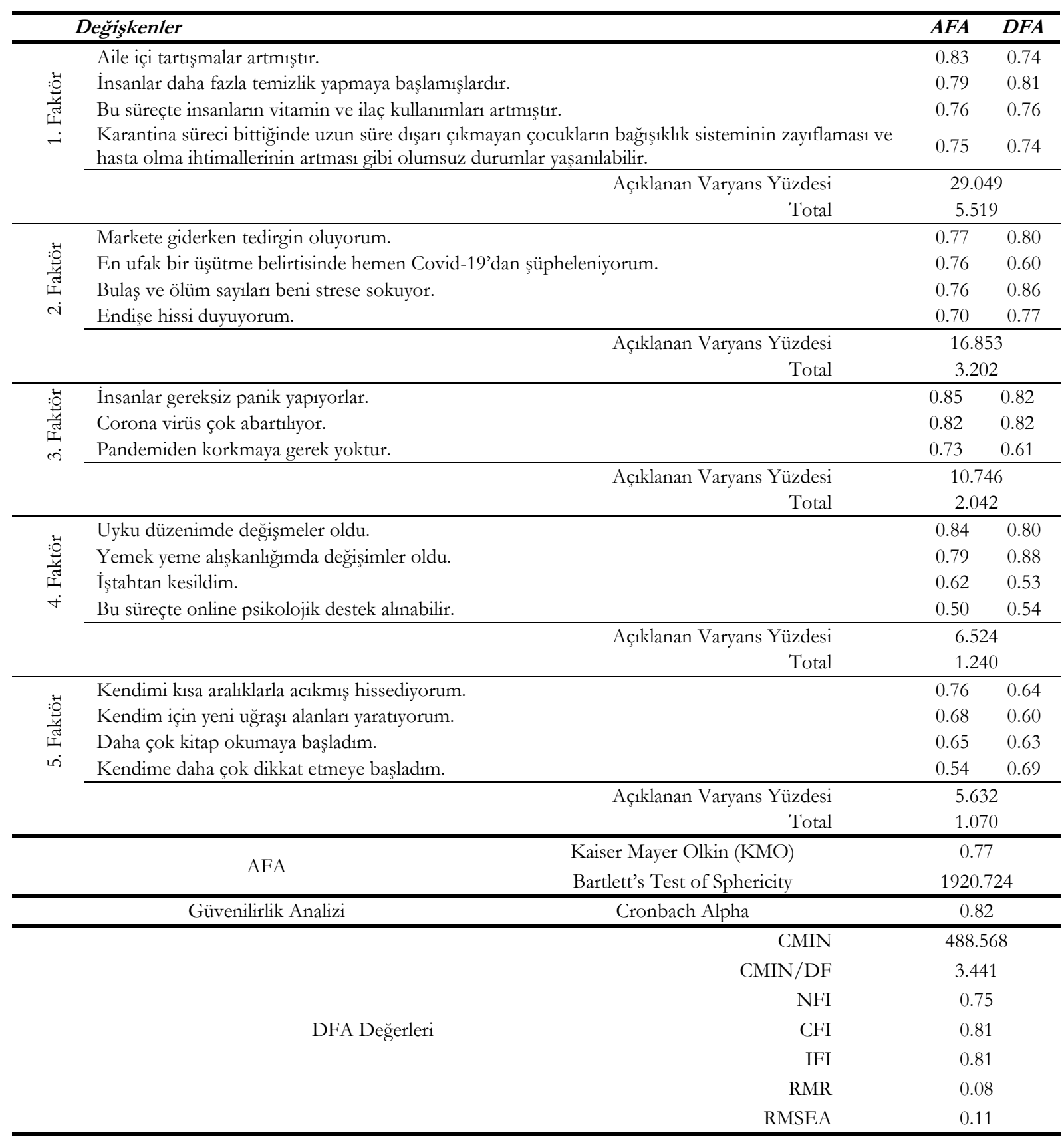

Tablo 3, Tablo 4 ve son olarak Tablo 5'te katılımcıların demografik değişkenleri ve analiz sonucunda elde edilen faktörler ile aralarındaki korelasyon yapısını saptayabilmek adına korelasyon analizi yapılmıştır. Yapılan analizler sonucunda, elde edilen sonuçlar Tablo 3, Tablo 4 ve Tablo 5'de verilmiştir.

Tablo 3'te verilen sonuçlara göre, cinsiyet ile covid-19 dönemi duygu ve durumları ölçeğindeki sırasıyla 2. faktör $\mathrm{p}=0.000,3$. faktör $\mathrm{p}=0.028$ ve 4 . faktör $\mathrm{p}=0.000$ arasında, $(\mathrm{p}<0.05)$ değerinde anlamlı bir ilişki olduğu belirlenmiştir. Tablo 4'de verilen sonuçlara göre, katılımcıların yaş değişkeni ile covid-19 dönemi duygu ve durumları ölçeğindeki 4 . faktör $\mathrm{p}=0.037$ arasında, $(\mathrm{p}<0.05)$ değerinde anlamlı bir ilişki olduğu belirlenmiştir. Son olarak Tablo 5'de verilen sonuçlara göre, katılımcıların okudukları okul ile covid-19 
dönemi duygu ve durumları ölçeğindeki sırasıyla 1. faktör $\mathrm{p}=0.000$, 2. faktör $\mathrm{p}=0.001$, 4. faktör $\mathrm{p}=0.000$ ve 5. faktör $\mathrm{p}=0.041$ arasında, $(\mathrm{p}<0.05)$ değerinde anlamlı bir ilişki olduğu belirlenmiştir.

Buna ek olarak, faktörlerin ortalama değerleri incelendiğinde $X=4.1400, X=3.6700, X=2.6800$, $\mathrm{X}=3.4338$ ve son olarak $\mathrm{X}=3.8675$ olduğu saptanmıştır. Farklı bir açıdan bakıldığında ise, katılımcılar 1 . faktöre kesinlikle katılmıyorum yönünde olduğunu gösterirken, 2. faktör, 4. faktör ve 5. faktör ise katılmıyorum yönünde olduğu görülmektedir. Son olarak 3 . faktör ise kararsız cevabına yönelik olduğu saptanmiştır.

Tablo 3. Korelasyon ve Ortalama Değerler

\begin{tabular}{lccccccc}
\hline & \multicolumn{7}{c}{ Korelasyon } \\
\hline \multicolumn{1}{c}{ Cinsiyet } & $\mathrm{X}$ & 1 & 2 & 3 & 4 & 5 & 6 \\
1. Faktör & 1.4350 & 1 & & & & & \\
2. Faktör & 4.1400 & -.054 & 1 & & & \\
3. Faktör & 3.6700 & -.433 & .293 & 1 & & \\
4. Faktör & 2.6800 & .155 & .069 & -.252 & 1 & & \\
5. Faktör & 3.4338 & -.264 & .225 & .592 & -.054 & .294 & 1 \\
\hline
\end{tabular}

Tablo 4. Korelasyon ve Ortalama Değerler

\begin{tabular}{|c|c|c|c|c|c|c|c|c|}
\hline \multicolumn{9}{|c|}{ Korelasyon } \\
\hline & & $\bar{X}$ & 1 & 2 & 3 & 4 & 5 & 6 \\
\hline & Yaş & 2.4400 & 1 & & & & & \\
\hline 1. Faktör & & 4.1400 & .082 & 1 & & & & \\
\hline 2. Faktör & & 3.6700 & .047 & .293 & 1 & & & \\
\hline 3. Faktör & & 2.6800 & .027 & .069 & -.252 & 1 & & \\
\hline 4. Faktör & & 3.4338 & .148 & .225 & .592 & -.054 & 1 & \\
\hline 5. Faktör & & 3.8675 & .065 & .562 & .277 & .161 & .294 & 1 \\
\hline
\end{tabular}

Tablo 5. Korelasyon ve Ortalama Değerler

\begin{tabular}{|c|c|c|c|c|c|c|c|c|}
\hline \multicolumn{9}{|c|}{ Korelasyon } \\
\hline & & $\bar{X}$ & 1 & 2 & 3 & 4 & 5 & $\overline{6}$ \\
\hline & Okudukları okul & 4.0850 & 1 & & & & & \\
\hline 1. Faktör & & 4.1400 & .249 & 1 & & & & \\
\hline 2. Faktör & & 3.6700 & .224 & .293 & 1 & & & \\
\hline 3. Faktör & & 2.6800 & -.060 & .069 & -.252 & 1 & & \\
\hline 4. Faktör & & 3.4338 & .282 & .225 & .592 & -.054 & 1 & \\
\hline 5. Faktör & & 3.8675 & .145 & .562 & .277 & .161 & .294 & 1 \\
\hline
\end{tabular}

Covid-19 dönemi duygu ve durumları ölçeğindeki değişkenler ve cinsiyet, yaş ve okudukları okul ile aralarında anlamlı bir fark olup olmadığın belirleyebilmek adına çoklu regrasyon analizi yapılıp elde edilen sonuçlar ise Tablo 6'da verilmiştir. Gerçekleştirilmiş olan bu analiz sonucunda, çalışmaya katılım sağlayan kişilerin cinsiyetleri, yaşları ve okudukları bölümler ile covid-19 dönemi duygu ve durumları ölçeğindeki değişkenlerinden bazılarıyla arasında anlamlı bir fark olduğu saptanırken, bazılarıyla anlamlı bir fark olmadığı ortaya çıkmıştır. Tablo 6'da verilen $\mathrm{R}^{2}$ değeri, bağımlı değişkenlerdi varyasyonun yüzde kaçlık değerinin bağımsız değişken doğrultusunda ortaya çıktığı bilinmektedir (Dursun ve Kocagöz, 2010). Oluşturulmuş olan modeller elde edilen $\mathrm{R}^{2}$ değerleri sırasıyla 0.213 ; 0.028; 0.121 olduğu saptanmıştır. Elde edilen değer, covid-19 dönemi duygu ve durumları ile cinsiyet, yaş ve okudukları okul duygu ve durumlarının sırasıyla $\% 21 ; \% 2 ; \% 12$ 'sini açıklamaktadır. Gerçekleştirilmiş olan bu çalışmadaki regrasyon tablosu toplamda üç modelden oluşmaktadır.

Oluşturulmuş model 1'de katılımcıların covid-19 dönemi duygu ve durumları ölçeğinin ikinci faktör ve beșinci faktörü ile cinsiyet arasında anlamlı $(\mathrm{p}<0.05)$ bir fark olduğu saptanmıștır. Model 1'de elde edilen Durbin-Watson test sonucunda 2.242 olduğu belirlenmiştir. Elde edilen bu sonuca göre hata terimleri ile arasında bir korelasyon olmadığı saptanmıştır (Şencan, Veri Analizi, t.y.). Model 2'de katıllımcıların covid-19 dönemi duygu ve durumları ölçeğinin dördüncü faktörü ile yaş arasında anlamlı $(p<0.05)$ bir fark olduğu saptanmıştır. Model 2'de elde edilen Durbin-Watson test sonucunda 1.861 olduğu belirlenmiştir. Elde edilen bu sonuca göre hata terimleri ile arasında bir korelasyon olmadığı saptanmışır. Son olarak 
Model 3'de katılımcıların covid-19 dönemi duygu ve durumları ölçeğinin birinci faktör ve dördüncü faktörü ile okudukları okul arasında anlamlı $(\mathrm{p}<0.05)$ bir fark olduğu saptanmıştır. Model 3'de elde edilen Durbin-Watson test sonucunda 1.844 olduğu belirlenmiştir. Elde edilen bu sonuca göre hata terimleri ile arasında bir korelasyon olmadığı gerçekleştirilen çoklu regrasyon analizi sonucunda saptanmıştır.

Tablo 6. Coklu Regrasyon Analizi Tablosu

\begin{tabular}{|c|c|c|c|c|c|c|c|c|c|c|}
\hline Değişkenler & B & S.E & $\beta$ & $t$ & $p$ & Tolerans & $V I F$ & $\boldsymbol{R}$ & $R^{2}$ & $\begin{array}{l}\text { Durbin- } \\
\text { Watson }\end{array}$ \\
\hline \multicolumn{11}{|l|}{ Model 1: Cinsiyet } \\
\hline Sabit & 1.889 & .194 & & 9.739 & .000 & & & \multirow{6}{*}{.462} & \multirow{6}{*}{.213} & \multirow{6}{*}{2.242} \\
\hline 1. Faktör & -.005 & .044 & -.008 & -.108 & .914 & .663 & 1.508 & & & \\
\hline 2. Faktör & -.204 & .039 & -.447 & -5.268 & .000 & .564 & 1.774 & & & \\
\hline 3. Faktör & .006 & .030 & .013 & .197 & .844 & .872 & 1.147 & & & \\
\hline 4. Faktör & -.022 & .038 & -.047 & -.582 & .561 & .627 & 1.596 & & & \\
\hline 5. Faktör & .097 & .046 & .170 & 2.118 & .035 & .632 & 1.582 & & & \\
\hline \multicolumn{11}{|l|}{ Model 2: Yaş } \\
\hline Sabit & 1.650 & .527 & & 3.133 & .002 & & & \multirow{6}{*}{.168} & \multirow{6}{*}{.028} & \multirow{6}{*}{1.861} \\
\hline 1. Faktör & .089 & .119 & .065 & .748 & .455 & .663 & 1.508 & & & \\
\hline 2. Faktör & -.081 & .105 & -.072 & -.769 & .443 & .564 & 1.774 & & & \\
\hline 3. Faktör & .016 & .081 & .015 & .199 & .842 & .872 & 1.147 & & & \\
\hline 4. Faktör & .206 & .103 & .179 & 1.998 & .047 & .627 & 1.596 & & & \\
\hline 5. Faktör & -.008 & .125 & -.006 & -.068 & .946 & .632 & 1.582 & & & \\
\hline \multicolumn{11}{|l|}{$\begin{array}{l}\text { Model 3: Okuduklar1 } \\
\text { okul }\end{array}$} \\
\hline Sabit & 1.169 & .782 & & 1.494 & .137 & & & \multirow{6}{*}{.348} & \multirow{6}{*}{.121} & \multirow{6}{*}{1.844} \\
\hline 1. Faktör & .470 & .177 & .219 & 2.649 & .009 & .663 & 1.508 & & & \\
\hline 2. Faktör & .042 & .157 & .024 & .266 & .791 & .564 & 1.774 & & & \\
\hline 3. Faktör & -.083 & .120 & -.050 & -.690 & .491 & .872 & 1.147 & & & \\
\hline 4. Faktör & .412 & .153 & .229 & 2.689 & .008 & .627 & 1.596 & & & \\
\hline 5. Faktör & -.097 & .185 & -.044 & -.521 & .603 & .632 & 1.582 & & & \\
\hline
\end{tabular}

Tartışma, Sonuç ve Öneriler

Geçmişten günümüze kadar olan süreçler içerisinde meydana gelen covid-19 virüs salgını gibi salgın hastalıklardan tüm dünya etkilenmektedir. Ancak bu durum eskiye nazaran günümüzde salgın hastalıkların yayılma hızı daha fazla artmaktadır. Değiş̧en ve gelişen ulaşım araçları, insanların artık sadece kendi yaşadıkları bölgeler dışında, başka ülkeler ve şehirlerde iş yapmaları yani değişen ve gelişen iş sahaları, refah düzeyi ile doğru oranlı olarak değişen turizm algisı ve turizmin yllın dört mevsiminde gerçekleşebilmesi gibi sebepler nedeni ile insanlar günümüzde oldukça hızlı bir şekilde dünyanın her yerine salgın hastalıkları bilmeyerek farklı bölgelere taşıyabilmektedir. Covid-19 virüsü de Çin'in Wuhan kentinden başlayıp oldukça hızlı bir şekilde tüm dünyaya yayılarak ülkelerin sınır kapılarını kapatmalarına, eğitim ve öğretimin online platformlarda yürütülmesine kısacası pandemi sürecinin başlamasına neden olmuştur.

Covid-19 virüsü insanların birbirine olan temaslarından kaynaklı oldukça kolay bir şekilde yayılabilmekte olduğu için ilk olarak okulları yüz yüze eğitim yerine uzaktan eğitime yönlendirerek herkesin evlerinden katılımı sağlandı ve ülkeler arası giriş ve çıkışlara sınırlamalar getirildi. Böylelikle virüsün teması bir süreliğine engellendi. Ancak pandemi süresinde insanların ruhsal ve sosyal durumlarında istemedik birtakım olumsuzluklar meydana gelmeye başladı. Tüketim alışkanlıklarında, sosyal ilişkilerinde, özellikle eğitim ve öğretim hayatına yeni başlayan çocuklarda ve genç bireylerdeki ders çalışma durumlarında olmak üzere değişim meydana gelmiştir. Buna ek olarak ülkelerin ekonomilerinde oldukça çöküşler meydana gelmiştir. Bu durumun başlıca sebeplerinden biri turizm gerçekleşememesidir. Turizmin içerinde bulunan, alternatif turizm çeşitleri ile bölge halkıda kendilerine gelir ve kazanç sağlamaktadır. Şehir dışında ve yurtdışında eğitim gören insanların gittikleri bölgelerde hizmet veren yerel halka oldukça katkıları bulunmaktadır.

Yapılan bu araştırmada, KKTC'de eğitim gören genç bireylerin covid-19 virüsü nedeniyle yaşadıkları pandemi süresinde ruhsal ve sosyal olarak oldukça olumsuz yönde etkilenmiş oldukları sonucuna varılmıştır. Elde edilen sonuçlar ise alanyazında belirtilmiş olan olumsuzlukları destekleyen niteliktedir. Katılımcılanın aileleri ile yaşadıklanı iletişim problemleri, beslenme düzenlerinde gerçekleşen değişiklikler, kendi kişisel 
bakımlarında ve dış görünüşlerinde gerçekleşen değişiklikler olduğu saptanmıştır. Ayrıca başta seyahatlerin kısıtlanmasıyla, turizm gelirlerini ve turizmin alt boyutlarından gençlik turizminin gelirlerini de oldukça kötü bir şekilde etkilemiş olduğu görülmektedir. Gerçekleştirilmiş olan bu çalışma evren olarak, KKTC'de, üniversite düzeyinde eğitim gören genç bireyler tercih edilmiştir. Diğer araştırmacılar tarafindan, covid-19 virüs salgınının sebep olduğu olumsuzluklar incelenmek istendiği taktirde araştırma evreninin daha geniş olması tercih edilebilir. İlaveten iki bölge seçilerek elde edilen veriler arasında karşılaştırmalar yapılabilir. Geçmişte yaşanmış salgın hastalıklarda alınan önlemler ile covid-19 virüs salgında alınan önlemler, devlet politikaları gibi durumların da karşılaştırmaları yapılarak iyileştirici öneriler yapılabilir. Bu şekilde gerçekleştirilebilecek çalışmalar ileride tez araştırması yapacak olan öğrenciler ve diğer araştırmacılar için birincil kaynak olma özelliği taşıyabilecek niteliktedir.

\section{Etik Beyan}

“Üniversite Öğrencilerinin Covid-19 Dönemi Duygu ve Durumlarna İlişkin Tutumlar; KKTC Ömĕğ̨̆ başlıklı çalışmanın yazım sürecinde bilimsel kurallara, etik ve alıntı kurallarına uyulmuş; toplanan veriler üzerinde herhangi bir tahrifat yapılmamış ve bu çalışma herhangi başka bir akademik yayın ortamına değerlendirme için gönderilmemiştir. Gerekli olan etik kurul izinleri Doğu Akdeniz Üniversitesi Bilimsel Araştırma ve Yayın Etiği Kurulu'nun 02.10.2020 tarih ve 21 sayılı toplantısında alınmıştır.

\section{Kaynakça}

Acar, Y. (2020). Yeni Koronavirüs (COVID-19) salgını ve turizm faaliyetlerine etkisi. Güncel Turiz̨m Araștrmalarn Dergisi, 4(1), 7-21, doi: 10.32572/guntad.703410.

Akca, M. (2020). COVID-19'un havac1lik sektörüne etkisi. Avrasya Sosyal ve Ekonomi Arașttrmalarn Dergisi, 7(5), 45-64.

Aktuğ, İ. D. (2020). COVID-19 immün sistem ve egzersiz. International Journal of Human Sciences, 17(2), 513-520. doi: 10.14687/jhs.v17i2.6005.

Altunışık, R., Coşkun, R., Bayraktaroğlu, S. ve Yıldırım, E. (2007). Sosyal bilimlerde araştrma yöntemleri spss uygulamall. Sakarya: Sakarya Yayıncilik.

Ariyaratne, W. M. (2020). Post-COVID19 challenges and way forward for Sri Lanka tourism. Rajarata University of Sri Lanka, 1-12, doi: 10.2139/ssrn.3581509.

Bakar, N. A. ve Rosbi, S. (2020). Effect of Coronavirus disease (COVID-19) to tourism industry. International Journal of Advanced Engineering Research and Science, 7(4), 189-193, doi: 10.22161/ijaers.74.23.

Bozkurt, A. (2020). Koronavirüs (Covid-19) pandemi süreci ve pandemi sonrası dünyada eğitime yönelik değerlendirmeler: Yeni normal ve yeni eğitim paradigması. Açleöğretim Uygulamalar ve Araștrmalar Dergisi, 6(3), $112-142$.

Crawford, J., Butler-Henderson, K., Rudolph, J., Malkawi, B., Glowatz, M., Burton, R., Lam, S. (2020). COVID-19: 20 countries' higher education intra-period digital pedagogy responses. Journal of Applied Learning and Teaching, 3(1), 9-28. doi: 10.37074/jalt.2020.3.1.7.

Çakmur, H. (2012). Araştırmalarda ölçme - güvenilirlik - geçerlilik. TAF Preventive Medicine Bulletin, 11(3), 339-344.

Çöl, G. (2020). COVID-19 salgınına genel bir bakış. Ankara Üniversitesi T⿰亻 Fakïltesi.

Demuyakor, J. (2020). Coronavirus (COVID-19) and online learning in higher institutions of education: A survey of the perceptions of ghanaian international students in China. Online Journal of Communication and Media Technologies, 10(3), e202018. doi: 10.29333/ojcmt/8286.

Dikmen, K. ve Özkan, İ. (2020). COVID-19 epidemiyolojisi: Pandemiden ne öğrendik. Journal of Biotechnology and Strategic Health Research, 4(2), s. 29-36. doi: 10.34084/bshr.715153.

Doğan, N. ve Başokçu, T. O. (2010). İstatistik tutum ölçeği için uygulanan faktör analizi ve aşamalı kümeleme analizi sonuçlarının karşılaştırlması. Eğitimde ve Psikolojide Ölçme ve Değerlendirme Dergisi, 1(2), 65-71.

Durak, G. ve Serkan Çankaya, S. İ. (2020). Examining the Turkish universities' distance education systems during the COVID-19 pandemic. Necatibey Eğitim Fakïltesi Elektronik Fen ve Matematik Eğitimi Dergisi, 14(1), 787-809. doi: 10.17522/balikesirnef. 743080 .

Dursun, Y. ve Kocagöz, E. (2010). Yapisal eşitlik modellemesi ve regresyon: Karş̧laştırmalı bir analiz. Erciyes Üniversitesi İktisadi ve İdari Bilimler Fakilltesi Dergisi, 2(35), 1-17.

Ercan, İ. ve Kan, İ. (2004). Ölçeklerde güvenirlik ve geçerlik. Uludağ Üniversitesi Tip Fakïltesi Dergisi, 30(3), 211-216.

Erkorkmaz, Ü., Etikan, İ., Demir, O., Özdamar, K. ve Sanisoğlu, S. Y. (2013). Doğrulayıcı faktör analizi ve uyum indeksleri. Turkiye Klinikleri J Med Sci, 33(1), 210-223. doi: 10.5336/medsci.2011-26747.

Gössling, S., Scott, D. ve Hall, C. M. (2020). Pandemics, tourism and global change: A rapid assessment of COVID19. Journal of Sustainable Tourism, 29(1), 1-20, doi: 10.1080/09669582.2020.1758708.

İbiş, S. (2020). COVID-19 salgınının seyahat acentalari üzerine etkisi. Safran Kültür ve Turizm Araşstrmalar Dergisi, 3(1), $85-98$.

Karatosun, H. (2010). Fiziksel aktivite ve ruh sağlığı. SDÜ Yaşam Dergisi, 2(2), 9-13.

Kilıç, S. (2016). Cronbach'nn alfa güvenirlik katsayısı. Journal of Mood Disorders, 6(1), 47-48. 
Liu, S., Yang, L., Zhang, C., Xiang, Y.-T., Liu, Z., Hu, S. ve Zhang, B. (2020). Online mental health services in China during the COVID-19 outbreak. Published Online, 7(2), e17-e18. doi: 10.1016/S2215-0366(20)30077-8.

Macit, A. ve Macit, D. (2020). Türk sivil havacillk sektöründe COVID-19 pandemisinin yönetimi. Avrasya Sosyal ve Ekonomi Arastirmalar Dergisi, 7(4), 100-116.

Niewiadomski, P. (2020). COVID-19: from temporary de-globalisation to a re-discovery of tourism? Tourism Geographies, 22(3), 651-656. doi: 10.108/14616688.2020.1757749.

Özçiftçi, Ü. (2020). COVID-19 pandemisinin sosyal yaşam ve etik düzlem üzerine etkileri: Bir değerlendirme çalışmas1. Anadolu Kliniği Tep Bilimleri Dergisi, 25(1), 142-153. doi: 10.21673/anadoluklin.721864.

Pakpour, A. H. ve Griffiths, M. D. (2020). The fear of COVID-19 and its role in preventive behaviors. Journal of Concurrent Disorders, 4(3), 1-6.

Schermelleh-Engel, K., Moosbrugger, H. ve Müller, H. (2003). Evaluating the Fit of Structural Equation Models: Tests of Significance and Descriptive Goodness-of-Fit Measures. Methods of Psychological Research Online, 8(2), 2374.

Schleicher, A. (2020). A framework to guide an education response to the COVID-19 Pandemic of 2020. Cyprus: OECD 2020, 1-40.

Şen, M. A. (2020). Koronavirüs (Covid-19) salgınının Türkiye'deki yemek firmalarında oluşturduğu etkinin belirlenmesi üzerine bir araştırma. Afet ve Risk Dergisi, 3(1), 89-100. doi: 10.35341/afet.717513.

Şencan, H. (2005). Sosyal ve davranışsal ölçümlerde güvenilirlike ve geçerlilik. Ankara: Seçkin Yayıncılık Sanayi ve Ticaret A.Ş.

Şencan, H. (t.y.). Veri Analizi. Mayıs 27, 2020 tarihinde https://ders.es/ adresinden alındı

Şenışı, S. (2015). Egzersiz ve bağışıklık sistemi. Turk J Sports Med, 50(2), 11-20.

Sheresheva, M. Y. (2020). Coronavirus and tourism. Population and Economics, 4(2), 72-76. doi: $10.3897 /$ popecon.4.e53574.

Soylu, Ü. Ö. (2020). Türkiye ekonomisinde COVID-19'un sektörel etkileri. Avrasya Sosyal ve Ekonomi Arastrrmalar Dergisi, 7(5), 169-185.

Tezbaşaran, A. (1997). Likert tipi ölçek gelistirme kılavuzu. Ankara: Türk Psikologlar Derneği Yayınları.

Toquero, C. M. (2020). Challenges and opportunities for higher education amid the COVID-19 pandemic: The Philippine context. Pedagogical Research, 5(4), s. em0063.

Türkmen, M. ve Özsar1, A. (2020). Covid-19 salg1nı ve spor sektörüne etkileri. International Journal of Sport Culture and Science, 8(2), 55-67. doi: 10.14486/IntJSCS.2020.596.

TÜRSAB. (2020). Turizm istişare ... Mayıs 26, 2020 tarihinde https://www.tursab.org.tr adresinden alınd1

Üstün, Ç. ve Özçiftçi, S. (2020). COVID-19 pandemisinde sosyal yaşam ve etik düzlem üzerine etkileri: bir değerlendirme çalışması. Anadolu Kliniğ Tĭ Bilimleri Dergisi, 25(Özel Say1 1), 145-153. doi: 10.21673/anadoluklin.721864.

\section{EXTENDED ABSTRACT}

Covid-19 has rapidly spread to all parts of China and then to all countries of the world since the first Covid-19 case was reported in Wuhan, China at the end of 2019. Covid-19, which has become a global epidemic, has caused not only medical but also social, professional, political, economic, ethical and moral consequences. It was observed that the spread of the epidemic turned into a pandemic due to the countries not being ready for the Covid-19 epidemic, some delays and confusion in the measures to be taken, and the high rate of transmission of the disease. In short, depending on the possible reactions to be experienced during infectious disease outbreaks, the reactions that may be encountered in Covid-19 specific to Covid-19 can be summarized and additional, respectively: those who have been exposed to Covid-19, fear and anxiety about the individual's health status and loved one sleep hygiene or dietary changes, difficulty sleeping or concentration, worsening of chronic health problems if any, and increased use of alcohol, tobacco or other drugs In a population-based study; female gender, being a student, having symptoms suggestive of Covid-19, and perceived health status were associated with higher rates of anxiety and depression.

The outbreak of SARS-CoV-2 infection was named Corona virus Disease 2019 (Covid-19) by the World Health Organization (WHO) (Üstün, \& Özçiftçi, 2020). Covid-19 spread rapidly to many countries and was officially declared as a pandemic by the World Health Organization on March 11, 2020, with the death of more than 4000 people (Çöl, 2020). Covid-19 disease is a respiratory disease caused by a new corona virus and was first detected in Wuhan, China in December 2019. Although the source of this virus is not known clearly, it is thought to be transmitted from wild animals sold in the Huanan seafood wholesale market (Aktuğ, 2020). The disease is highly contagious, and its main clinical symptoms are fever, dry cough, fatigue, myalgia, and shortness of breath. Isolation, which is an important step in the control of this disease, has many physiological and psychological effects (Karatosun, 2010). It is very important for individuals to adapt to this life in order to be able to go through this process in a healthy way. During quarantine, it is essential to stay active and maintain a physical exercise routine for mental and physical 
health (Karatosun, 2010). It is very important to continue active life at home so that people's lifestyles do not change and their health does not deteriorate (Aktuğ, 2020).

In order to protect people from the Covid-19 virus epidemic, education has started to continue through the internet during the pandemic. However, there have been changes in the feelings and situations of the individuals. During the pandemic period, people moved away from their social and normal lives, causing negative consequences in all aspects (Toquero, 2020). These negativities caused changes in people's mental states. In order to prevent these, organizations have been carried out for people on internet platforms (Schleicher, 2020). In order to break in Education in Turkey all primary, secondary, high school and university systems was continued in building on the Internet. In addition, all exams were postponed (Durak, \& Çankaya, 2020). Internet access has been facilitated for many concerts based on performing arts such as theater and similar performances on the internet (Demuyakor, 2020). With all the educational, cultural and artistic organizations carried out, it was aimed to prevent the change in people and to spend the pandemic period more comfortably and healthily (Liu, et al., 2020; Pakpour, \& Griffiths, 2020).

This study aims to develop a valid, reliable and new attitude scale regarding the feelings and situations of students studying at their universities in TRNC during the Covid-19 period. According to the answers given, a 5-point Likert type 30-item questionnaire was applied to 203 university students in TRNC, and 200 of them were evaluated. SPSS 24.0 and AMOS 24.0 statistical package program were used for statistical calculations of the data obtained. While there were 40 items in the questionnaire form prepared in fivepoint Likert type, the number of items was reduced to 30 as a result of pre-application and analysis. The scale was made ready for use by obtaining data about the reliability and reliability of the scale. validity. As a result of the analysis, it was determined that the values and data obtained were at a good level. Also, according to the results of the multiple regression analysis, there is a significant difference between gender and age variables and the scale of emotion and state of the Covid-19 period, the participants' reading and the scale of the emotions and states of the Covid-19 period.

In this study, it was concluded that young individuals studying in the Turkish Republic of Northern Cyprus were affected negatively both mentally and socially during the pandemic period they experienced due to the Covid-19 virus. The results obtained support the negativities stated in the literature. It was found that the participants had communication problems with their families, changes in their diet, changes in their personal care and appearance. In addition, it is seen that tourism revenues and youth tourism, which is one of the sub-dimensions of tourism, have had a very bad effect on the income of tourism, especially with the restriction of travel. As the universe of this study, young individuals studying at university level in the Turkish Republic of Northern Cyprus were preferred. If it is desired to examine the adversities caused by the Covid-19 virus outbreak by other researchers, it may be preferable to have a larger research universe. In addition, comparisons can be made between the data obtained by selecting two regions. Curative suggestions can be made by comparing the measures taken in the past epidemic diseases with the measures taken in the Covid-19 virus epidemic, and state policies. Studies that can be carried out in this way can be a primary source for students and other researchers who will conduct a thesis research in the future. 